\title{
半溶融および半凝固状態の $\mathrm{Al}-\mathrm{Mg}$ 系合金の 力学特性の比較
}

\author{
座間 淳志 $*$,** · 利光 万弘 $*$ ・渡部 智也 $*$,*** \\ 千葉 浩行 $* * * *$. 鳥山 隆成 $*$ ****** . 吉田 誠 $* * * * * *$
}

Journal of The Japan Institute of Light Metals, Vol. 61, No. 9 (2011), 446-451

\section{Comparison of mechanical characteristics between semi-liquid state and semi-solid state in Al-Mg alloys}

\author{
Atsushi ZAMA $^{* * * *}$, Kazuhiro TOSHIMITSU**, Tomoya WATANABE*** \\ Hiroyuki CHIBA $^{\text {****** }}$, Takanari TORIYAMA ${ }^{* * * * * * * *}$ and Makoto YOSHIDA ${ }^{* * * * * * *}$
}

\begin{abstract}
In our previous works, tensile test devices for both semi-liquid and semi-solid aluminum alloys were developed. In this report, comparison of mechanical properties such as ultimate tensile strength (UTS) and fracture strain between semiliquid and semi-solid Al-Mg alloy was examined. Difference of the mechanical properties will be caused by the microstructural change during heating process in the tensile test of semi-liquid alloy. By constant load creep test to the semi-liquid alloy, about $90 \%$ deformation of permanent and $10 \%$ of elastic deformation were found. Thus, in the thermal-stress analysis, solid-liquid co-existence aluminum alloy should be dealt as visco-elastic or viscoelasto-plastic material rather than elasto-plastic material.
\end{abstract}

(Received January 24, 2011 Accepted April 14, 2011)

Keywords: solidification, cracking, die-casting, direct-chill casting, hot tear

\section{1. 緒言}

自動車の軽量化に向けてェンジン・駆動系部品はもとより, インナードアなどの大型車体部品へのアルミニウム合金やマ グネシウム合金ダイカストの適用が進められている。しかし 合金組成や鋳造条件によってはダイカストや半連続鋳造時に 凝固割れが発生し問題となっている。そこで凝固割れの予測 および製造プロセス上での制御が求められている。

CAE (Computer Aided Engineering) を用いて凝固割れの発 生を予測するためには，固液共存状態における応力ーひずみ 曲線および破断ひずみが必須となる。固液共存状態における 力学特性の取得方法として, 半溶融引張試験法と半凝固引張 試験法が挙げられる。著者らは，これらの引張試験方法 ${ }^{1) ~ 20) ~}$

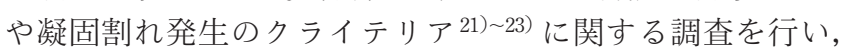
従来の引張試験方法の問題点を抽出した ${ }^{2), 3)}$ 。そして従来の 問題点を解決した引張試験装置を開発し， $\mathrm{Al}-\mathrm{Mg}$ 系合金の半
溶融および半凝固状態における応力 -ひずみ曲線と破断ひず

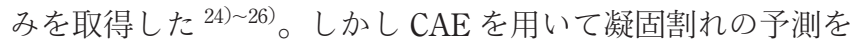
する上で, 以下の 2 点が課題となっており, それらの検討が なされた例はない。

（1）半溶融状態では試験片のミクロ偏析が軽減していくこ

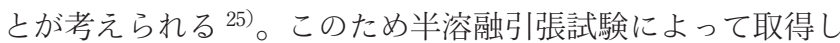
た力学特性を CAE に入力する場合，ミクロ偏析の軽減によ る組織变化が力学特性に及ぼす影響について考慮する必要が ある。

（2）CAE に適用する解析モデルを決定するため, アルミニ ウム合金の固液共存状態において生じたひずみを，弾性变形 および粘性，塑性変形に区別する必要がある。

そこで本研究では, 半凝固状態と半溶融状態での力学特性 の比較や半溶融状態に打ける試験片の組織变化に関する調 查, 半溶融状態での定荷重クリープ試験を行うことで, 上記 の課題の検討を行った。

* 早稲田大学大学院創造理工学研究科総合機械工学専攻大学院生（ 169-8555 東京都新宿区大久保 3-4-1)。Graduate Student, Major in Modern Mechanical Engineering, Graduate School of Creative Science and Engineering, Waseda University (3-4-1 Okubo Shinjuku-ku, Tokyo 169-8555).

** 現在：いすぐ自動車株式会社（Present: Isuzu Motors Ltd.）.

*** 現在：東京地下鉄株式会社（Present: Tokyo Metro Co., Ltd.)

*****早稲田大学大学院理工学研究科環境資源及材料理工学専攻物質材料理工学専門分野大学院生（東京都）〔現在：ホンダエンジニアリ ング株式会社」。Graduate Student, Major in Materials Science and Engineering, Graduate School of Science and Engineering, Waseda University （Shinjuku-ku, Tokyo) (Present: Honda Engineering Co., Ltd.〕.

****** 現在：トヨ夕自動車株式会社 (Present: Toyota Motor Corporation).

*******早稲田大学各務記念材料技術研究所 (東京都)。Kagami Memorial Research Institute for Materials Science and Technology, Waseda University (Shinjuku-ku, Tokyo). 
Table 1 Chemical composition of Al-Mg alloy for semi-liquid tensile test (a), semi-solid tensile test (b), semi-solid creep test (c) $(\operatorname{mass} \%)$

\begin{tabular}{c|c|c|c|c|c|c|c|c|c}
\hline \hline Composition & $\mathrm{Cu}$ & $\mathrm{Si}$ & $\mathrm{Mg}$ & $\mathrm{Zn}$ & $\mathrm{Fe}$ & $\mathrm{Mn}$ & $\mathrm{Ni}$ & $\mathrm{Ti}$ & $\mathrm{Al}$ \\
\hline (a) & 0.014 & 0.01 & 4.33 & 0.005 & 0.11 & 0.92 & 0.27 & 0.07 & $\mathrm{Bal}$ \\
\hline (b) & 0.000 & 0.13 & 4.66 & 0.000 & 0.11 & 0.66 & 0.33 & 0.07 & $\mathrm{Bal}$ \\
\hline (c) & 0.000 & 0.011 & 4.23 & 0.000 & 0.024 & 0.024 & 0.005 & 0.002 & $\mathrm{Bal}$ \\
\hline
\end{tabular}

(a)

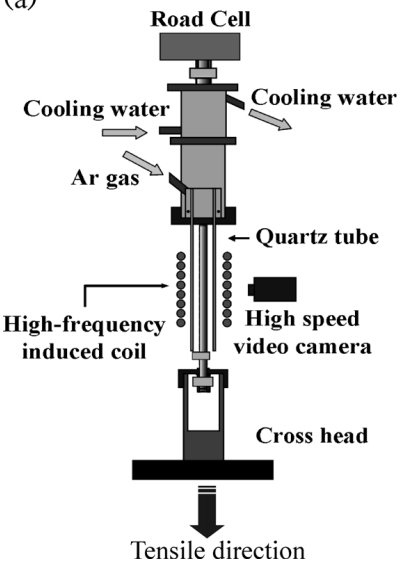

Fig. 1 Schematic of the semi-liquid tensile testing device.

\section{2. 実 験 方 法}

\section{1 半溶融引張試験}

\section{1 .1 供試材料}

AC7A アルミニウム合金にほぼ準じた $\mathrm{Al}-\mathrm{Mg}$ 系合金を用い て引張試験を行った。供試材料の組成を Table 1 に示す。引 張試験片は銅舟型を用いて重力鋳造により作製した。引張試 験片は $\phi 8 \mathrm{~mm}$, 全長 $210 \mathrm{~mm}$ の丸棒試験片の中央部に $\phi 6$ $\mathrm{mm}$, 長さ $10 \mathrm{~mm}$ のダンベル部を設けている。なお試験片ダ ンベル部の DAS II（デンドライト二次アームスペーシング） は交線法 ${ }^{27)}$ により測定すると $34 \mu \mathrm{m}$ であった。

\section{1 .2 半溶融引張試験の特徵}

著者らが開発した高周波誘導加熱による半溶融引張試験装 置の概略図を Fig. 1 (a) に示す。引張試験の特徵として以下 の 3 点が挙げられる ${ }^{25)}$ 。

（1）加熱中に試験片表面が酸化することを防ぐ必要がある。 そのため温度調節機能付きのエアヒータを用いてアルゴンガ スを熱し，約 $200^{\circ} \mathrm{C}$ のルゴンガス雾囲気中で引張試験を 行っている。

（2）加熱時の試験片の膨張によって発生する圧縮変形を防 止する必要がある。そこで Fig. 1（b）に示すように，引張試 験前は試験片の下部を自由にしておき，引張試験時にはクロ スヘッドを下げ，試験片の下端につけたナットとキャップ部 分が接触した時点で引張を開始する構造にしている。

（3）目標温度に到達した後，約 1 分間等温保持してから引 張速度 $50 \mathrm{~mm} / \mathrm{min}$ で試験をしている。そして高速度ビデオカ メラを用いて試験片につけたマーカの動きを可視化し, 応力 測定との時間同期をすることで応力 -ひずみ曲線を取得して いる。

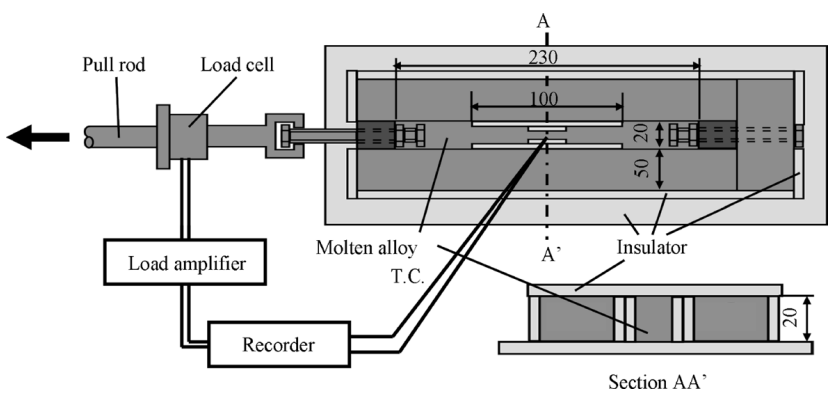

Fig. 2 Schematic of the semi-solid tensile testing device.
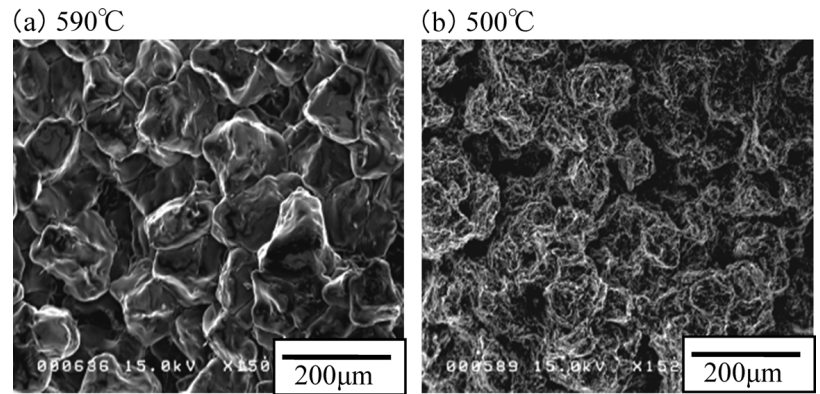

Fig. 3 Surfaces fractured at $590^{\circ} \mathrm{C}$ and $500^{\circ} \mathrm{C}$ in the semiliquid state observed by the scanning electron microscope.

\section{2 半凝固引張試験}

\subsection{1 供試材料}

半溶融引張試験と同様の $\mathrm{Al}-\mathrm{Mg}$ 系合金を用いている。供 試材料の組成を Table 1（b）に示す。なお凝固組織の DAS II は $68 \mu \mathrm{m}$ であった。

\section{2 .2 半凝固引張試験の特徵}

雄谷らの装置を参考に著者らが開発した半凝固引張試験装 置の概略図を Fig. 2 に示す。半凝固引張試験の特徴として以 下の 2 点が挙げられる ${ }^{26)} 。$

（1）引張試験装置内の金型に注湯した後，断熱材を貼付し た金型中央部分が最終凝固部となるようにしている。

（2）目標温度到達時に引張速度 $60 \mathrm{~mm} / \mathrm{min}$ で引張試験を 行っている。そして高速度ビデオカメラを用いて，マーカと したデンドライトの動きを可視化し, 応力測定との時間同期 をすることで応力 -ひずみ曲線を取得している。

\section{3 半溶融状態における試験片の組織変化に関する調査}

Fig. 3 (a),（b) に半溶融引張試験後，試験温度から常温に なるまで空冷した試験片破断面の SEM 画像を示す。Fig. 3 (a) は試験温度 $590^{\circ} \mathrm{C}$ に打ける破断面, Fig. 3 (b) は試験温度 $500^{\circ} \mathrm{C}$ に打ける破断面である。 $590^{\circ} \mathrm{C}$ での破断面では一つ一つ の結晶粒の粒面がはっきりしてくることから，粒界に液膜が 
存在していたことがうかがえる。一方 $500^{\circ} \mathrm{C}$ では結晶粒の粒 面が見られないことから，固相のみの状態であったことがう かがえる。そこで $590^{\circ} \mathrm{C}$ と $500^{\circ} \mathrm{C}$ で等温保持した後に水冷し た試験片の溶質元素分布を測定し, 半溶融状態および固相の みの状態での試験片の組織変化について検討した。等温保持 時間は目標温度到達後 0 分， 1 分， 2 分間とした。そして各 温度保持時間の後, 水冷した試験片のダンベル中心部を切出 して研磨し，中心部付近の 5 か所で SEM-EDX を用いて組成 分析を行った。そして Fig. 4 に示すように，デンドライトの 境界部の（1）デンドライト間隙，（2）デンドライト内での 溶質濃度を調査した。

\section{4 定荷重クリープ試験}

供試材料には $\mathrm{Al}-5 \mathrm{mass} \% \mathrm{Mg}$ 合金を用いた。この合金組成 を Table 1 (c) に示す。試験片の作製方法および形状は 2.1 と 同じである。まず試験片を $568^{\circ} \mathrm{C}$ と $578^{\circ} \mathrm{C}$ に加熱した。なお $568^{\circ} \mathrm{C}$ で半溶融引張試験を行った際の試験片破面の SEM 写真 を Fig. 5 に示す。Fig. 5 より結晶粒の粒面が確認できること から， $\mathrm{Al}-5 \mathrm{mass} \% \mathrm{Mg}$ 合金は $568^{\circ} \mathrm{C}$ 以上では固液共存状態之 なることがわかる。そして等温保持した状態のままで試験片 に一定の負荷（約 $0.7 \mathrm{MPa）を} 60$ 秒間加え，その後除荷する という定荷重クリープ試験を行った。変位測定にはレーザ変 位計を用いて，試験片下部に取付けたアルミニウム製の反射

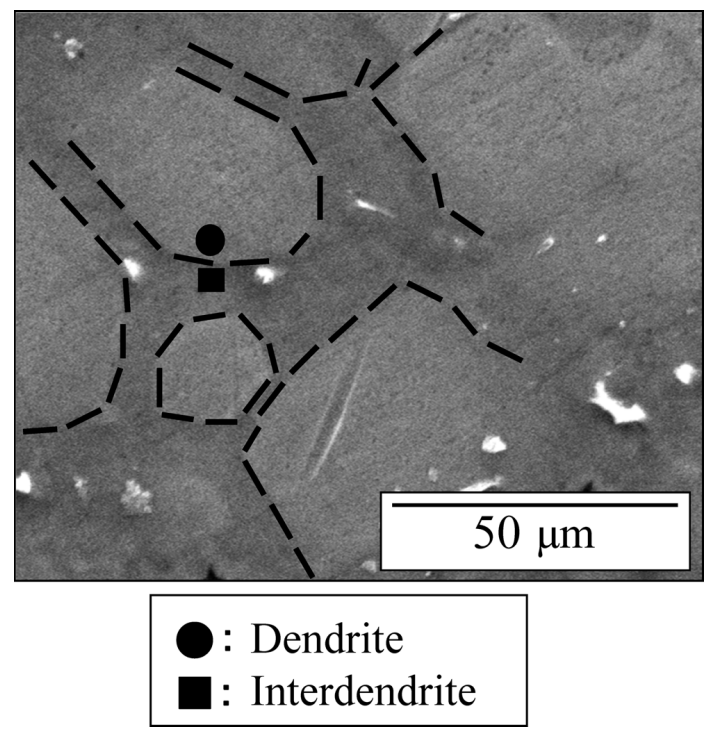

Fig. 4 Dendrite and interdendrite positions in microstructure.

(a) UTS

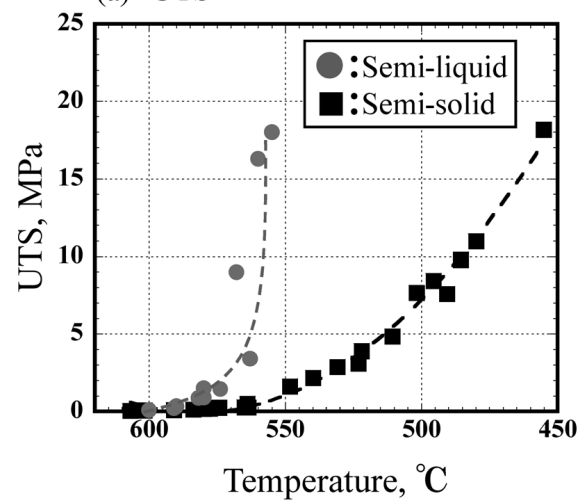

板の動きを負荷開始から除荷後 30 秒まで測定した。

試験片に負荷をかける方法は以下の通りである。試験片の 下部に穴をあけ，そこにカーボンテープを通す。カーボン テープに錘を括り付けることで試験片に錘による荷重がかか るようにした。またカーボンテープを弛ませた状態のまま, 錘を引張試験機のクロスヘッドの上に置くことで，負荷開始 まで試験片に荷重がかからないようにした。これにより負荷 開始の際にはクロスヘッドを下げ, カーボンテープのゆるみ をなくすことで錘による負荷が試験片にかかるようにした。 一方で除荷の際には, クロスヘッドを上昇させカーボンテー プをゆるませることで荷重を取除くようにした。

\section{3. 実験結果および考察}

\section{1 半溶融状態と半凝固状態での力学特性の比較}

2.1 および 2.2 の手法で取得した $\mathrm{Al}-\mathrm{Mg}$ 系合金の最大引張 強さと温度の関係を Fig. 6 (a) に, 破断ひずみと温度の関係 を Fig. 6 (b) に示す。Fig. 6 (a), (b) より, 最大引張強さおよ び破断ひずみの急激に増加する温度は半溶融引張試験時の方 が半凝固引張試験時と比べて $100^{\circ} \mathrm{C}$ ぼ高温になることがわ かった。

半溶融引張試験では試験片の再加熱および等温保持によっ てミクロ偏析部が溶融し, いわゆるメルトバック現象や等温 凝固が発生した可能性がある ${ }^{28)}$ 。これにより試験片の組織が ミクロ偏析を有した状態からより均一な状態へと恋化し, 固

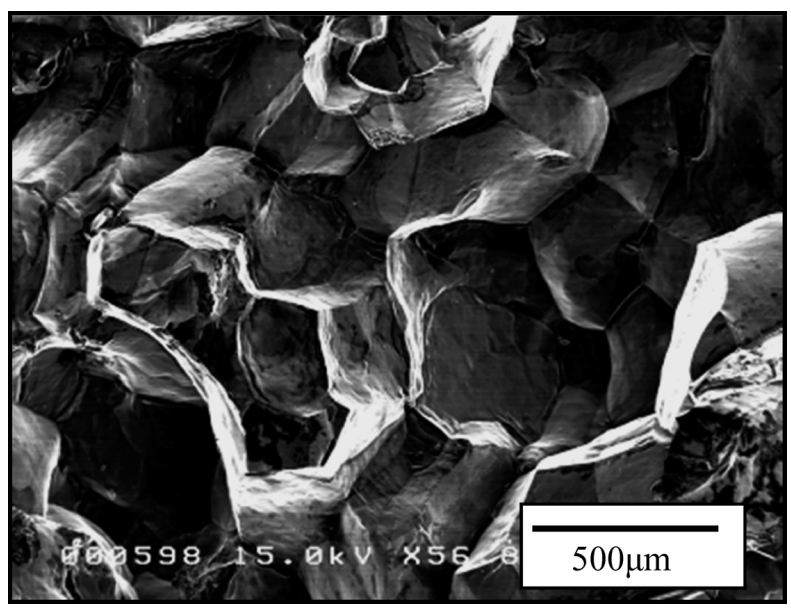

Fig. 5 Surface fractured at $568^{\circ} \mathrm{C}$ in the semi-liquid state observed by the scanning electron microscope.

(b) Fructure strain

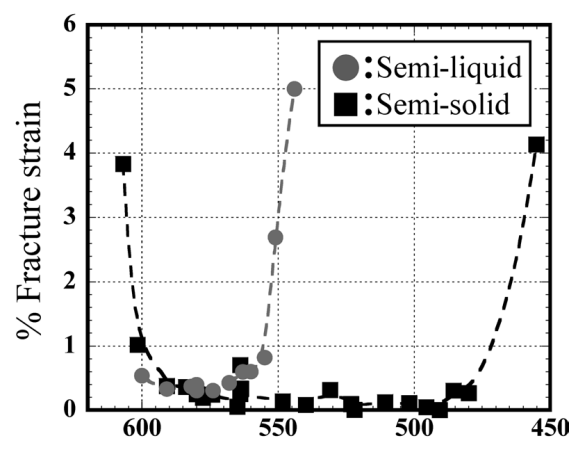

Temperature, ${ }^{\circ} \mathbf{C}$

Fig. 6 Relationship between temperature and mechanical properties obtained by semi-solid and semi-liquid tensile tests. 
(a) $590^{\circ} \mathrm{C}$

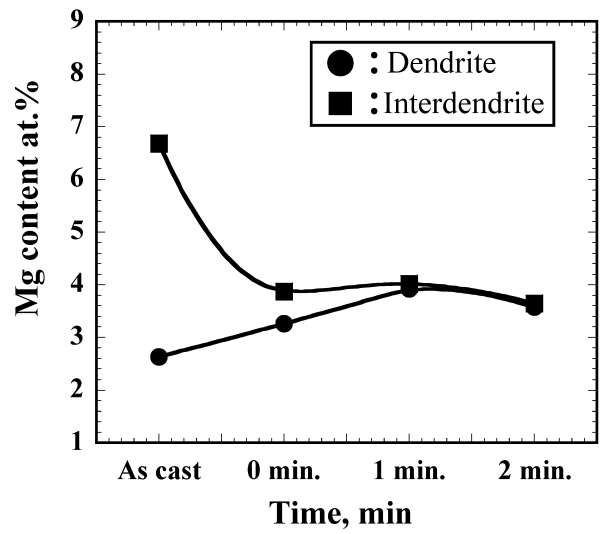

(b) $500^{\circ} \mathrm{C}$

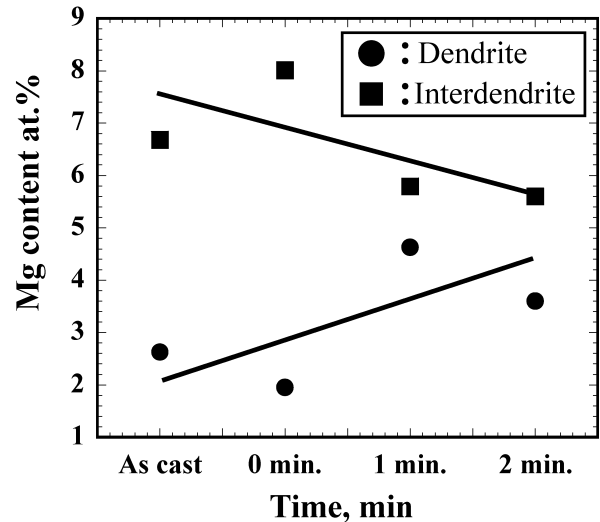

Fig. 7 Change in concentration of magnesium due to isothermal treatment.

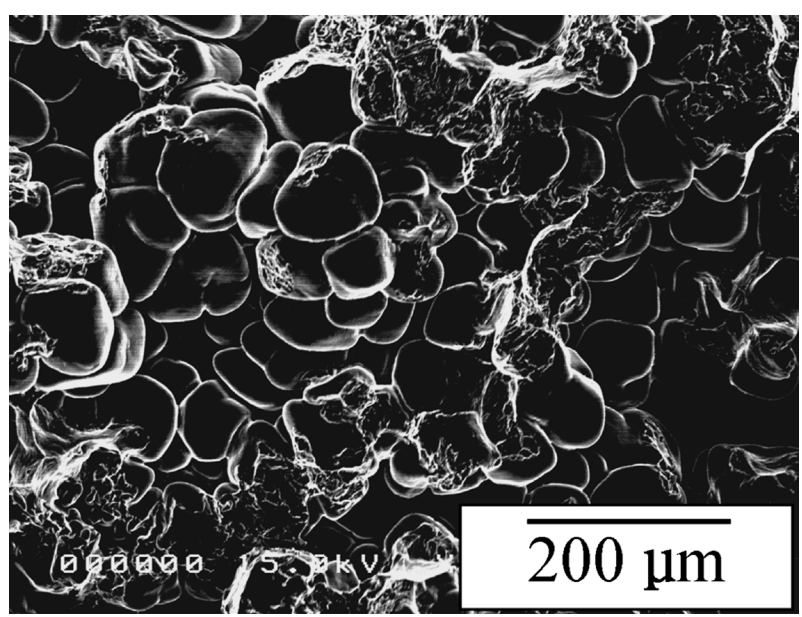

Fig. 8 Surface fractured at $448^{\circ} \mathrm{C}$ in the semi-solid state observed by the scanning electron microscope.

相線温度が半凝固状態よりも高温になったと推測される。

\section{2 半溶融状態における試験片の組織変化の程度}

2.3 の手法により調査した, 溶質元素であるマグネシウム 濃度と等温保持時間の関係を Fig. 7 (a)，（b）に示す。Fig. 7 (a) は $590^{\circ} \mathrm{C}$ で等温保持したときのマグネシウム濃度と等温 保持時間の関係である。加熱前の試験片のマグネシウム濃度 はデンドライト間隙では約 $7 \mathrm{at} \%$, デンドライト内では約 3at％であることから, 試験片にはミクロ偏析が存在してい たことがわかる。そして等温保持時間が増すごとにマグネシ ウム濃度は均一になり, 温度保持時間 1 分以降でのマグネシ ウム濃度はデンドライト間隙，デンドライト内ともに約 $4 \mathrm{at} \%$ となった。

Fig. 7 (b) は $500^{\circ} \mathrm{C}$ で等温保持したときのマグネシウム濃度 之温度保持時間の関係である。 $500^{\circ} \mathrm{C}$ では温度保持時間 1 分 でのマグネシウム濃度はデンドライト間隙で約 $6 \mathrm{at} \%$, デン ドライト内で約 $4 \mathrm{at} \%$ となり，その後保持時間を増してもマ グネシウム濃度は均一にならなかった。

\section{3 固相率による半溶融状態と半凝固状態との力学特性 の比較}

3.1 および 3.2 より, 試験片の再加熱によってミクロ偏析 が軽減していく傾向が認められた。つまり半溶融引張試験で はミクロ偏析の軽減により供試材料の固相線温度は半凝固状 態よりむ高温になる。そこで温度ではなく固相率を用いて半

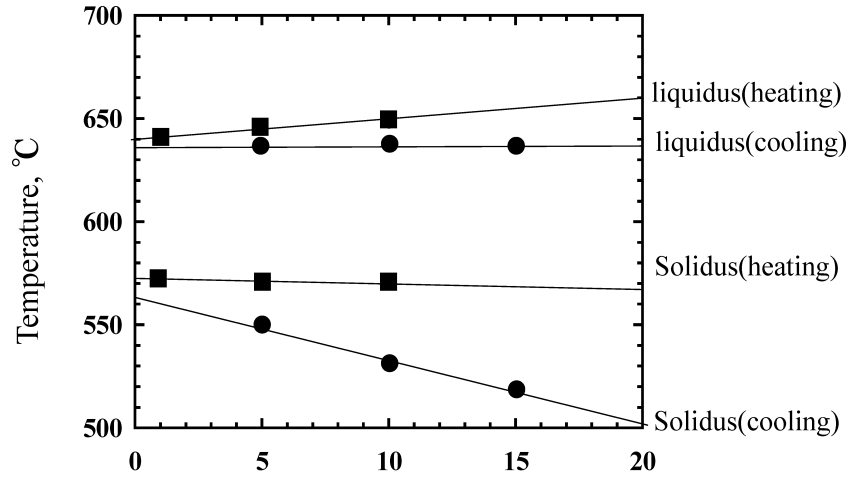

Heating and cooling rate, ${ }^{\circ} \mathrm{C} / \mathrm{min}$

Fig. 9 Solidus and liquidus estimated by the differential scanning calorimetry.

溶融状態と半凝固状態での力学特性を比較した。

半凝固状態では Scheil-Gulliver モデルによる温度と固相率 の関係を用いた（JMatPro ver. 5, ThermoTech 社使用）。なお Scheil-Gulliver モデルにより算出した固相線温度は $448^{\circ} \mathrm{C}$ であ る。 $448^{\circ} \mathrm{C}$ で半凝固引張試験を行った際の試験片の破断面の SEM 画像を Fig. 8 に示す。Fig. 8 にはデンドライトが確認さ れるため, 固相線温度 $448^{\circ} \mathrm{C}$ 以上の温度では引張試験時に固 液共存状態であったと考えられる。

半溶融状態ではミクロ偏析の軽減を考慮したため, 温度と 固相率の関係には DSC (Differential Scanning Calorimeter, 示 差走査熱分析）測定の結果を用いた。DSC 測定により推測し た固相線温度と冷却および昇温速度の関係を Fig. 9 に示す。 なお昇温過程では $400^{\circ} \mathrm{C}$ から $700^{\circ} \mathrm{C}$ までを速度 $1,5,10^{\circ} \mathrm{C} / \mathrm{min}$ で測定し, 冷却過程では $700^{\circ} \mathrm{C}$ から $400^{\circ} \mathrm{C}$ までを速度 5,10 , $15^{\circ} \mathrm{C} / \mathrm{min}$ で測定した。固相率は熱流量と温度の関係から式 （1）により算出した。

$$
f_{\mathrm{s}}=\frac{H_{\mathrm{T}}}{H_{\text {all }}}
$$

式中の $H_{\mathrm{T}}$ は各温度までの凝固潜熱, $H_{\mathrm{all}}$ は総凝固潜熱であ る。

Fig. 9 より昇温速度 $0^{\circ} \mathrm{C} / \mathrm{min}$ の外挿值を読取ると, $\mathrm{Al}-\mathrm{Mg}$ 系合金の固相線温度および液相線温度はそれぞれ $572^{\circ} \mathrm{C}$, $640^{\circ} \mathrm{C}$ となった。長海は, DSC 曲線から求めた合金の固相線 温度は平衡状態図に基づいた固相線温度と一致すると報告し

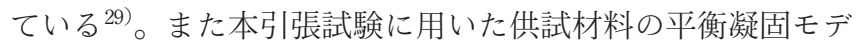




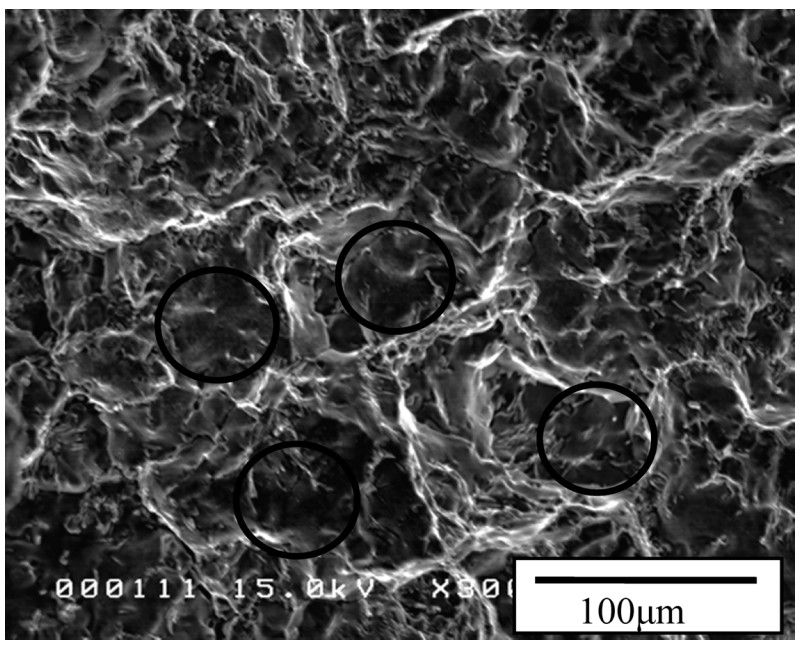

Fig. 10 Surface fracture at $550^{\circ} \mathrm{C}$ in the semi-liquid state observed by the scanning electron microscope.

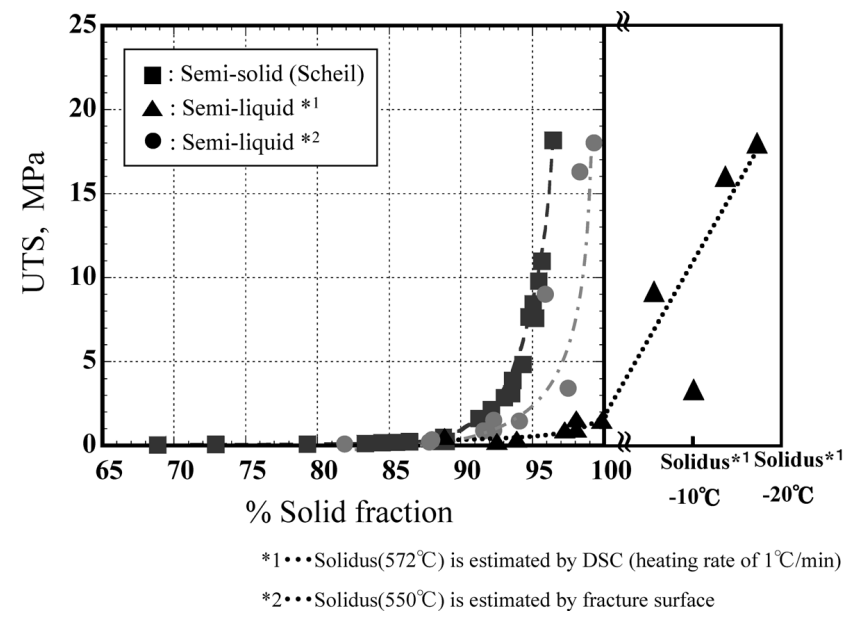

Fig. 11 Relationship between UTS and solid fraction obtained by the semi-solid and semi-liquid tensile test.

ルでの固相線温度（熱力学計算ソフトウェア (JMatPro ver. 5, ThermoTech 社）使用）が $576^{\circ} \mathrm{C}$ であることも考慮すると， DSC 測定中の試料の組織は平衡凝固組織に近い状態であった と考えられる。

しかし $550^{\circ} \mathrm{C}$ で半溶融引張試験を行ったときの試験片の破 断面（Fig. 10 に示す）を見ると，固液共存状態の特徵であ るなめらかな結晶粒の粒面が確認できる（Fig. 10 の丸枠内）。 このことから半溶融引張試験時には, ミクロ偏析が完全に消 失せず，試験片の組織は均一でなかったことが考えられる。 そこで半溶融状態での温度と固相率の関係には, 固相線温度 之液相線温度が昇温速度 $0^{\circ} \mathrm{C} / \mathrm{min}$ の外挿值とほぼ同じである 昇温速度 $1^{\circ} \mathrm{C} / \mathrm{min}$ での DSC 測定結果とともに，破面観察結果 を考慮して固相線温度が $550^{\circ} \mathrm{C}$ となる冷却速度 $5^{\circ} \mathrm{C} / \mathrm{min}$ での DSC 測定結果む用いた。

Fig. 11 に最大引張強さと固相率の関係を, Fig. 12 に破断 ひずみと固相率の関係を示す。半凝固状態の場合，最大引張 強さは固相率が $90 \%$ 以上になると急激に増加し，破断ひず みは固相率が $95 \%$ 以上になると急激に増加した。一方，半 溶融状態では, 温度と固相率の関係に昇温速度 $1^{\circ} \mathrm{C} / \mathrm{min}$ での DSC 測定結果を用いた場合，最大引張強さおよび破断ひずみ はともに固相線温度 $\left(572^{\circ} \mathrm{C}\right)$ を下回ってから急激に増加し

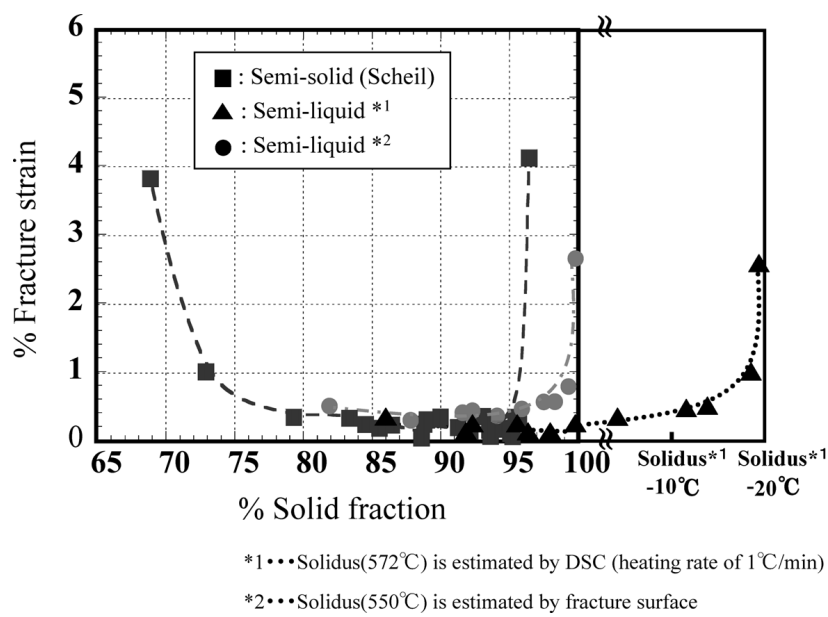

Fig. 12 Relationship between fracture strain and solid fraction obtained by the semi-solid and semi-liquid tensile test.

た。また破面観察結果を考慮して, 半溶融状態での温度と固 相率の関係に冷却速度 $5^{\circ} \mathrm{C} / \mathrm{min}$ での DSC 測定結果（固相線温 度 $550^{\circ} \mathrm{C}$ ) を用いた場合, 最大引張強さは固相率が $95 \%$ 以上 になると急激に増加し，破断ひずみは固相率が $100 \%$ になる と急激に増加した。

従来研究では固相率が約 90 95\% 以上で最大引張強さや延 性が急激に増加すると報告されている2),3)。半凝固引張試験 時ではScheil-Gulliver モデルにより算出した温度と固相率の 関係を用いることで, 力学特性と固相率の関係は従来研究と 同様の傾向を示すことがわかった。

半溶融引張試験では昇温時の DSC 測定によって推定した固 相線温度を用いると, 固相線温度以下になってから伸びや強 度は急激に上昇した。一方で破面観察により固相線温度を推 測し, このときの温度と固相率の関係を用いることで, 力学 特性之固相率は従来研究 ${ }^{2), 3)}$ 之同様の傾向を示すことがわ かった。それゆえに半溶融引張試験の場合は, Scheil-Gulliver モデルや平衡モデルではなく, 昇温中のミクロ偏析の軽減を 考慮した温度と固相率の関係について検討することが必要と なる。

\section{4 定荷重クリープ試験}

2.4 の手法で取得した, 試験温度 $568^{\circ} \mathrm{C}, 578^{\circ} \mathrm{C}$ におけるひ ずみと時間の関係を Fig. 13 (a)，(b) に示す。ひずみは試験 片のダンベル部 $(10 \mathrm{~mm})$ を標点間距離として算出した。

試験温度 $568^{\circ} \mathrm{C}$ では 60 秒間の負荷によって約 $3.2 \%$ のひず みが生じていたが，除荷とと屯にひずみは約 $2.7 \%$ に減少し た。つまり 60 秒間の負荷によって生じた約 $3.2 \%$ のひずみの うち $0.5 \%$ は弾性分であったと考えられる。また試験温度 $578^{\circ} \mathrm{C}$ に扔いては 60 秒間の負荷によって約 $1.4 \%$ のひずみが 生じ，除荷とともにひずみ $1.3 \%$ に減少した。このことから $578^{\circ} \mathrm{C}$ では負荷によって生じた $1.4 \%$ のひずみのうち $0.1 \%$ は 弾性分であったと考えられる。以上の結果から, 半溶融状態 のアルミニウム合金の変形には時間依存性があり, 粘性的な 挙動を有することが示唆された。つまり固液共存状態での引 張ひずみは粘弾性あるいは粘弾塑性であることが示唆された。

またこの調査から得られた最大ひずみは，半溶融状態にお ける引張試験（引張速度 $50 \mathrm{~mm} / \mathrm{min}$ ）から得られた破断ひず みよりも 3.5 倍ほど大きい。この点から, 引張速度が遅くな 
(a) $568^{\circ} \mathrm{C}$

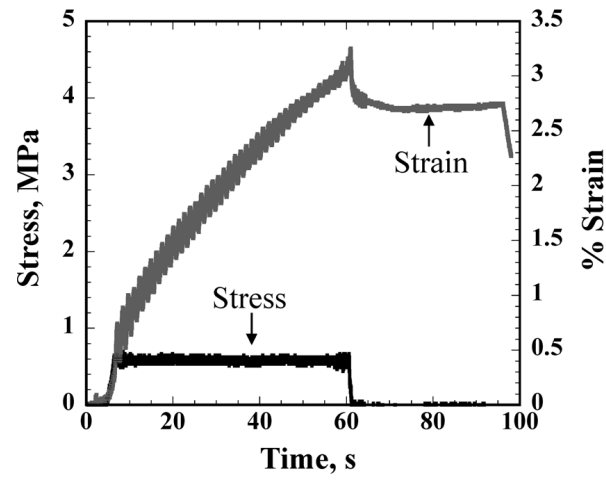

(b) $578^{\circ} \mathrm{C}$

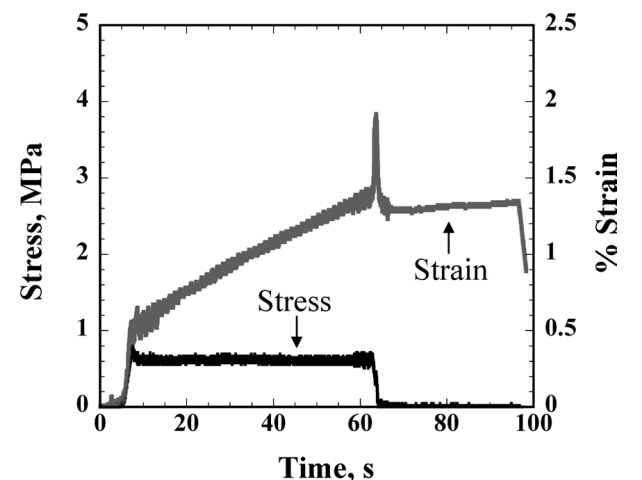

Fig. 13 Relationship between strain and time during a semi-liquid creep test.

るほど破断ひずみは大きくなることが示唆される。将来, CAE を用いて凝固割れの発生を予測する際には，ひずみ速度 について考慮する必要があると考えられる。

\section{4. 結言}

本研究では著者らの独自の装置を用いて, 半溶融と半凝固 状態における $\mathrm{Al}-\mathrm{Mg}$ 系合金の力学特性を取得し，その比較 および検討を行った。そのまとめを以下に述べる。

（1）半凝固状態における力学特性については, 固相率が $100 \%$ に近づくと最大引張強度と破断ひずみは急激に増加す る。

（2）温度における最大引張強さおよび破断ひずみは半溶融 状態のときの方が半凝固状態のときよりも大きい。この理由 に再加熱によるミクロ偏析の軽減が挙げられる。そのため半 溶融状態では, ミクロ偏析の軽減の程度に対応した固相率に ついて検討する必要がある。

（3）半溶融状態での変形には時間依存性があり, 弾性的な 挙動と粘性的な挙動を示した。このことから固液共存状態で のひずみは粘弾性あるいは粘弾塑性であることが示唆された。 謝 辞

本研究の遂行にあたり，ご指導を賜りました広島大学 篠 崎賢二教授, 日本軽金属株式会社 北岡山治博士に厚く御礼 を申し上げます。

また様々な助言および助力を頂きました, 早稲田大学客員 教授（現岐阜大学金型創成技術研究センター教授）山縣 裕博士，日本軽金属株式会社 長海博文博士，鈴木 聡氏， リョービ株式会社 浅田 穣博士，古河スカイ株式会社（現 古河テクノリサーチ株式会社) 大瀧光弘博士, 日産自動車株 式会社 神戸洋史博士に深甚なる感謝の意を表します。

なお本研究の一部は, ヤマ八発動機株式会社から頂いた研 究助成, および財団法人浦上奨学会（リョービ株式会社）か ら頂いた研究助成により実施致しました。関係各位に感謝の 意を表します。

\section{参 考 文 献}

1) D. G. Eskin, Suyitno and L. Katgerman: Progress in Materials Science, 49 (2004), 629-711.
2）渡部智也, 鳥山隆成, 木村亮介, 中澤 嵩, 千葉浩行, 田中宗 平，植木 徹，吉田 誠：軽金属， 58 (2008), 395-405.

3) 渡部智也, 鳥山隆成, 木村亮介, 中澤 嵩, 千葉浩行, 田中宗 平, 植木 徹, 吉田 誠：軽金属, 58 (2008), 464-472.

4) A. R. E. Singer and S. A. Cottrell: J. Inst. Met., 73 (1947), 33-54.

5) A. R. E. Singer and P. H. Jennings: J. Inst. Met., 73 (1947), 197-212.

6) I. I. Novikov: Goryachelomkost Tsvetnykh Metallov i Splavov, Moscow: Nauka (1966), 299.

7）千々岩健児，林 守仁：鋳物， 51 (1979), 270-275.

8）林 守仁：東海大学紀要工学部, (1982), 105-115.

9）財団法人素形材センター調査報告書, (1986).

10） C. S. Lin and J. A. Sekhar: Journal of Material Science, 28 (1993), 35813588.

11） C. S. Lin and J. A. Sekhar: Journal of Material Science, 28 (1993), 38853894.

12) C. S. Lin and J. A. Sekhar: Journal of Material Science, 29 (1994), 36373642.

13) C. S. Lin and J. A. Sekhar: Journal of Material Science, 29 (1994), 50055013.

14) J. A. Spittle, S. G. R. Brown, J. D. James and R. W. Evans: Proc 7th Intern symp. on Physical Simulation of Casting, Hot Rolling and Welding, Tsukuba National Research Institute for Metals, (1997), $81-91$.

15) Q. Han, M. I. Hassan, S. Viswanathan, K. Saito and S. K. Das: Metallurgical and Materials Transaction A, 36A (2005), 2073-2080.

16）篠崎賢二：溶接学会全国大会講演集，80（2007), F13-F17.

17） B. Forest and S. Bercovici: The Metal Society, (1983), 607.

18) B. Magnin, L. Katgerman and B. Hannart: Metals and Materials Society, (1995), 303.

19) W.-M. van Haaften, W. H. Kool and L. Katgerman: Light Metals, 28 (1999), 239.

20) D. J. Soel, Y. M. Won, K. H. Oh, Y. S. Shin and C. H. Yim: ISIJ International, 40 (2000), 356.

21）座間淳志，吉田 誠：鋳造工学，82 (2010), 583-589.

22) 座間淳志, 吉田 誠：鋳造工学, 82 (2010), 640-646

23）座間淳志，遠藤 至，吉田 誠：鋳造工学, 82 (2010), 697-701,

24）座間淳志, 渡部智也, 利光万弘, 千葉浩行, 鳥山隆成, 山縣 裕, 吉田 誠: 日本鋳造工学会全国講演大会講演概要集, 154 (2009), 70 .

25）座間淳志，中澤 嵩，利光万弘，吉田 誠：軽金属，(投稿中）

26）千葉浩行, 植木 徹, 鳥山隆成, 遠藤 至, 小林昂光, 吉田 誠：軽金属, (投稿中).

27）軽金属学会 鋳造・凝固部会編：軽金属，38（1988）, 54-60.

28）溶接学会 溶接冶金研究委員会編：溶接学会技術資料, 15 (2003), 355-370

29）長海博文：軽金属， 50 (2000), 49-53. 